\title{
Immunofluorescence Detection of Nitrogenase Proteins in Whole Cells
}

\author{
By R. J. RENNIE \\ A.R.C. Unit of Nitrogen Fixation, University of Sussex, Brighton BNI $9 Q J$
}

(Received I2 July 1976)

\begin{abstract}
SUMMARY
Fluorescent antibodies (FA) prepared against the Mo-Fe and Fe proteins of nitrogenase from Klebsiella pneumoniae M5aI were used to detect these protein components in toluene-treated whole cells that were actively reducing acetylene. The FA were highly specific, staining only nitrogenase component proteins originating from Klebsiella. Cross-reactions between the FA and purified nitrogenase proteins from other dinitrogen-fixing micro-organisms did not occur, except in the case of Bacillus polymyxa. The tests rapidly and accurately assayed the component proteins in Klebsiella mutants and derivatives to which Klebsiella nif genes had been transferred either by plasmid or by other means. Cross-reactions also indicated the degree of relatedness between nitrogenase proteins from dinitrogen-fixing micro-organisms of various origins.
\end{abstract}

\section{INTRODUCTION}

Fluorescent antibodies (FA) have been widely used in microbial ecology (Schmidt, 1973) for the identification and enumeration of micro-organisms in various habitats. FA have also been used as 'tracers' to locate and study enzymes in animal cells (Goldman, 1968; Nairn, 1969), but have not been used to study intracellular enzymes in micro-organisms since bacterial membranes are impermeable to antibodies (Kwapinskyi, 1972). Once the wall and membrane have been damaged, however, one would expect intracellular enzymes to be readily stained with their specific, homologous FA.

Nitrogenase, the enzyme which reduces dinitrogen, is a binary protein consisting of nonhaem Mo-Fe and Fe proteins, and has been well characterized (Eady \& Postgate, 1974). Immunological detection of the two protein components as cross-reacting material (CRM) has involved serial dilutions in Preer tubes (Davis et al., 1972), modifications of the Ouchterlony plate technique (Shah et al., 1973), or polyacrylamide gel electrophoresis (Brill et al., 1974). The immunological detection limit of the FA technique is I $\mu \mathrm{g}_{\text {protein }} \mathrm{ml}^{-1}$, compared with $0.05 \mu \mathrm{g} \mathrm{ml}^{-1}$ for quantitative agglutination, $0.1 \mu \mathrm{g} \mathrm{ml}^{-1}$ for flocculation, and $0.3 \mu \mathrm{g} \mathrm{ml}^{-1}$ for immunodiffusion (Kwapinskyi, 1972); but once the antigen-antibody complex has been formed, the conjugated dye may be detected at concentrations of I $\mathrm{pg} \mathrm{m}^{-1}$ and is subjectively easier to observe (Nairn, I969).

This paper reports the preparation of FA against purified nitrogenase proteins from Klebsiella pneumoniae M5aI and their use in genetic and biochemical studies involving nitrogenase. 


\section{METHODS}

Antibody induction. The Mo-Fe and $\mathrm{Fe}$ proteins of nitrogenase were purified from Klebsiella pneumoniae M5a (Eady et al., 1972; Smith et al., 1976) and diluted in pyrogen-free, de-gassed $0.85 \%(\mathrm{w} / \mathrm{v}) \mathrm{NaCl}(\mathrm{pH} 8 \cdot 0)$. The solution was divided into lots equivalent to $100 \mu \mathrm{g}$ nitrogenase; these were frozen as small beads in liquid nitrogen. Antibody formation was induced in New Zealand rabbits by four intramuscular injections at 2-day intervals of I00 $\mu \mathrm{g}$ protein diluted I: I (v/v) with Freund's complete adjuvant, followed by two intravenous injections without adjuvant at 2-day intervals. After 4 days rest, the rabbits were test bled through the marginal ear vein to determine antibody titre and then $20 \mathrm{ml}$ blood was removed by cardiac puncture, allowed to coagulate, and the antiserum was removed and frozen.

Antibody purification. All operations were at $4{ }^{\circ} \mathrm{C}$. To $10 \mathrm{ml}$ undiluted antiserum in a centrifuge tube, an equal volume of $3.9 \mathrm{M}-\left(\mathrm{NH}_{4}\right)_{2} \mathrm{SO}_{4}$ was added slowly, with stirring, and allowed to stand for $16 \mathrm{~h}$. After centrifuging at $10000 \mathrm{~g}$ for $\mathrm{Io} \mathrm{min}$, the protein precipitate was redissolved in $10 \mathrm{ml}$ saline; the precipitation procedure was repeated three times, but omitting the $16 \mathrm{~h}$ settling period. The final precipitate, in $10 \mathrm{ml} \mathrm{saline,} \mathrm{was} \mathrm{dialysed} \mathrm{against}$ saline until no sulphate or ammonium could be detected. Gamma globulins (IgG) were further purified with DEAE-cellulose using phosphate-buffered saline [PBS; containing $\left(\mathrm{g} \mathrm{l}^{-1}\right): \mathrm{Na}_{2} \mathrm{HPO}_{4}, \mathrm{II} \cdot 52 ; \mathrm{NaH}_{2} \mathrm{PO}_{4} \cdot 2 \mathrm{H}_{2} \mathrm{O}, 4 \cdot 48 ; \mathrm{NaCl}, 8 \cdot 50$; adjusted to $\mathrm{pH} 7 \cdot 2$ with I M$\mathrm{NaOH}]$ as the eluant (Kwapinskyi, 1972). The protein content of the globulin solution was determined by the biuret procedure (Gornall, Bardawill \& David, I949) and the solution was adjusted to $\mathrm{I} \cdot 0 \%(\mathrm{w} / \mathrm{v})$ protein with saline and stored at $-20^{\circ} \mathrm{C}$.

Conjugation. Globulin solution ( $10 \mathrm{ml}$ ) was mixed with $4.0 \mathrm{ml} 0.15 \mathrm{M}$-sodium phosphate buffer $\mathrm{pH} 9.0$, added to a solution of $4.0 \mathrm{ml} 0.10 \mathrm{M}$-sodium phosphate buffer $\mathrm{pH} 8.0$ and FITC Isomer I [fluorescein isothiocyanate, Sigma; $0.02 \mathrm{mg} \mathrm{FITC} \mathrm{(mg} \mathrm{protein)}{ }^{-1}$ ], the volume was made up to $20 \mathrm{ml}$ with saline and the $\mathrm{pH}$ was adjusted to 9.0 with $0^{\circ} \mathrm{I} \mathrm{M}-\mathrm{NaOH}$. The mixture was stirred for $6 \mathrm{~h}$ at $25^{\circ} \mathrm{C}$ after which conjugated and unconjugated FITC were separated on a column of Sephadex G-25 usingPBS as the eluant. The fluorescent antibody was dispensed in $\mathrm{I} \cdot 0 \mathrm{ml}$ quantities into sterile bijoux and stored frozen at $-20^{\circ} \mathrm{Cuntil}$ required.

Bacteria. Bacteria were transferred from slants to nutrient broth and grown for $24 \mathrm{~h}$, and a I \% inoculum was added to the appropriate medium: NFDM (Cannon, Dixon \& Postgate, 1974a) for Klebsiella and Salmonella Nif ${ }^{+}$strains; NFDM with $100 \mu \mathrm{g}$ aspartate $\mathrm{ml}^{-1}$ for Agrobacterium, $K$. aerogenes and Klebsiella Nif- strains; Burk's sucrose (Newton, Wilson \& Burris, 1953) for Azotobacter and Beijerinckia; Hino and Wilson's medium (Hino \& Wilson, 1957) for Clostridium and Bacillus; Kalininskaya's medium, with sodium lactate in place of ethanol, for Rhodospirillum and Spirillum (Biggins \& Postgate, 1969); and NFDM supplemented with $100 \mu \mathrm{g}$ Casamino acids $\mathrm{ml}^{-1}$ (for Escherichia coli c603) or $25 \mu \mathrm{g}$ tryptophan $\mathrm{ml}^{-1}$ (for $E$. coli JC5466). Bacteria were grown in $25 \mathrm{ml}$ Erlenmeyer flasks, sealed with a Suba-Seal and shaken on a rotary shaker at $30^{\circ} \mathrm{C}$, and were sampled at mid-exponential phase $\left(10^{6}\right.$ to $10^{8}$ cells $\left.\mathrm{ml}^{-1}\right)$ and assayed for acetylene-reducing activity. Samples $(0 \cdot 0 \mathrm{Iml})$ were placed within a I $\times I \mathrm{~cm}$ marked area on a sterile glass slide, $0.05 \mathrm{ml}$ toluene was added, and the solution was evaporated to a smear at $34^{\circ} \mathrm{C}$ and heat fixed by slowly passing the slide through a flame three times.

Enzymes. The oxygen-sensitive nitrogenase enzymes were maintained under argon. Samples (o.0r ml; I mg protein $\mathrm{ml}^{-1}$ ) were transferred under anaerobic conditions on to sterile glass slides in a BBL Gas Pack container which was sealed under an atmosphere of argon, hydrogen and $\mathrm{CO}_{2}$. The container was maintained at $34{ }^{\circ} \mathrm{C}$ until the solution had 
Table I. Immunological specificity of fluorescent antibodies (FA) prepared against the $\mathrm{Mo}-\mathrm{Fe}$ and $\mathrm{Fe}$ proteins of nitrogenase from Klebsiella pneumoniae M5aI

Test
'Normal' serum FA used to stain Klebsiella
pneumoniae nitrogenase
Homologous, unconjugated (unlabelled)
serum, followed by homologous conjugated
serum (FA)
Stain with homologous FA that has been
absorbed with antigen
Stain KpI with $\mathrm{K}_{1} \dagger$
with $\mathrm{K}_{2}$
Stain Kp2 with $\mathrm{K}_{\mathbf{I}}$
with $\mathrm{K}_{2}$

Objective

Antigen should be non-reactive, i.e. negative to non-specific staining

Blocking of specific sites with unlabelled antibody should prevent specific staining

Absorption should remove all or most of the staining reaction

Test cross-reactions between protein fractions

Test cross-reactions between protein fractions
Antibody stain*

$-$
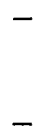

$+4$

$-$

$+$

$*$-, Negative; \pm , trace; + I feeble to +4 maximal.

$\dagger \mathrm{KpI}$ and $\mathrm{Kp} 2$ are Mo-Fe and Fe proteins of nitrogenase respectively; $\mathrm{K}_{\mathrm{I}}$ and $\mathrm{K}_{2}$ are fluorescent antibodies prepared against proteins $I$ and 2 respectively.

evaporated to a smear. The smear was then heat fixed by slowly passing the slide through a flame three times.

Staining. The appropriate FA (FA prepared against the Mo-Fe and $\mathrm{Fe}$ proteins of $K$. pneumoniae $\mathrm{M} 5 \mathrm{I}$ are designated $\mathrm{K}_{\mathrm{I}}$ and $\mathrm{K}_{2}$ respectively) was thawed slowly, diluted I :4 (v/v) with PBS, filter sterilized using a Sweeney filter and $0.45 \mu \mathrm{m}$ Millipore filter, and kept cold until required. Smears of bacteria and pure enzymes were stained with $0.5 \mathrm{ml}$ rhodamine gelatin solution to control autofluorescence and non-specific staining (Bohlool \& Schmidt, I968) and dried at 50 to $60^{\circ} \mathrm{C}$. $\mathrm{KI}_{\mathrm{I}}$ or $\mathrm{K}_{2}(0.5 \mathrm{ml})$ was added, and the slides were incubated in a moist chamber for 15 min and then washed with PBS for $30 \mathrm{~min}$. Slides were dried, mounted with Difco U.V. Free Mounting Media-Aqueous and covered with a $19 \mathrm{~mm}$ coverslip.

Microscopy. Slides were viewed on a Leitz Orthoplan fluorescence microscope equipped with a Wotan HBO $200 \mathrm{~W}$ super pressure mercury lamp and a tungsten white lamp, both in transmitted mode. Excitation of the FITC at $490 \mathrm{~nm}$ was by $2 \mathrm{~mm} \mathrm{KGI}$ heat filter, $3 \mathrm{~mm}$ $\mathrm{BG}_{3} 8,3 \mathrm{~mm} \mathrm{BGI}_{2}, \mathrm{I} \cdot 5 \mathrm{~mm} \mathrm{BGI}_{2}$ and $\mathrm{KP}_{500}$ filters in conjunction with a $\mathrm{K}_{5} \mathrm{Io}$ barrier filter. Plano $10 / 25 / 40$ objectives were used in conjunction with phase 5 , bright or dark field fluorescence microscopy. The fields viewed showed green fluorescing organisms and fluorescing debris from toluene-lysed cells. Fluorescence brightness of staining was determined qualitatively.

\section{RESULTS AND DISCUSSION}

The immunological specificities of the FA prepared against the Mo-Fe and $\mathrm{Fe}$ proteins of nitrogenase were evaluated according to the criteria of Schmidt (1973). The FA (Table I) were highly specific, exhibiting no non-specific staining or cross-reactions, and absorption effectively blocked the staining as expected.

\section{Reactions with proteins}

Cross-reactions between $\mathrm{K}_{\mathrm{I}}$ and $\mathrm{K}_{2}$ and nitrogenase proteins isolated from other dinitrogen-fixing bacteria as well as some related enzymes are shown in Table 2. $\mathrm{K}_{\mathrm{I}}$ and $\mathrm{K}_{2}$ stained 
Table 2. Cross-reactions of fluorescent antibodies against Klebsiella pneumoniae M5aI nitrogenase with purified nitrogenase from other dinitrogen-fixing micro-organisms and with other molybdenum-containing proteins

\begin{tabular}{|c|c|c|c|c|}
\hline & & & & \\
\hline Enzyme & Origin & Source & KI & $\mathbf{K}_{2}$ \\
\hline $\left.\begin{array}{l}\text { Nitrogenase protein } \\
\text { KpI* } \\
\text { Kp2 }\end{array}\right\}$ & K. pneumoniae M5aI & R. R. Eady & $\left\{\begin{array}{l}+4 \\
-\end{array}\right.$ & $\overline{+}$ \\
\hline $\left.\begin{array}{l}\text { Ac1 } \\
\text { Ac2 } 2\end{array}\right\}$ & Azotobacter chroococcum & M. G. Yates & $\left\{\begin{array}{l}\overline{ \pm} \\
\end{array}\right.$ & $\overline{ \pm}$ \\
\hline $\left.\begin{array}{l}\mathrm{Cp} 1 \\
\mathrm{Cp} 2\end{array}\right\}$ & Clostridium pasteurianum & L. E. Mortenson & $\left\{\begin{array}{l}- \\
-\end{array}\right.$ & $\overline{-}$ \\
\hline $\left.\begin{array}{l}\text { BpI } \\
\text { Bp2 }\end{array}\right\}$ & Bacillus polymyxa & B. E. Smith & $\left\{\begin{array}{l}+3 \\
-\end{array}\right.$ & $\overline{+}$ \\
\hline $\mathrm{RjI}$ & Rhizobium japonicum bacteroids & F. Bergersen & - & - \\
\hline Glutamine synthetase & $\begin{array}{l}\text { Adenylated } K . \text { aerogenes MK } 53 \\
\text { Deadenylated } K . \text { aerogenes MK } 53 \\
\text { Deadenylated } E . \text { coli }\end{array}$ & S. L. Streicher & $\overline{-}$ & $\overline{-}$ \\
\hline $\begin{array}{l}\text { Xanthine oxidase } \\
\text { Nitrate reductase }\end{array}$ & $\begin{array}{l}\text { E. coli } \\
\text { E. coli }\end{array}$ & $\begin{array}{l}\text { R. C. Bray } \\
\text { R. C. Bray }\end{array}$ & $\overline{-}$ & $\overline{-}$ \\
\hline $\begin{array}{l}\text { Formate dehydrogenase } \\
\text { Bovine serum albumin }\end{array}$ & E. coli & $\begin{array}{l}\text { R. C. Bray } \\
\text { Sigma }\end{array}$ & $\overline{-}$ & $\overline{-}$ \\
\hline
\end{tabular}

* Proteins $\mathrm{I}$ and 2 are $\mathrm{Mo}-\mathrm{Fe}$ and $\mathrm{Fe}$ proteins of nitrogenase respectively.

$\dagger-$, Negative; \pm , trace; $+\mathrm{I}$ feeble to +4 maximal.

Table 3. Staining of toluene-treated micro-organisms actively reducing acetylene with fuorescent antibodies against nitrogenase from Klebsiella pneumoniae M5a I

Micro-organism

K. pneumoniae M5a I

$K$. pneumoniae MaI $\left(\mathrm{NH}_{4}{ }^{+}\right.$-repressed)

Antibody stain*

K. pneumoniae 107

Klebsiella serotype 54

Klebsiella serotype 54(1 28 I-70)

$K$. aerogenes 418

$K$. aerogenes MK54

Azotobacter vinelandii oP

Az. chroococcum 8003

Beijerinckia indica 8597

Bacillus polymyxa 8599

Clostridium pasteurianum 9486

Rhodospirillum rubrum 8740

Spirillum lipoferum 7

Sp. lipoferum $\mathrm{Br} 10$

Sp. lipoferum M81

Sp. lipoferum $5 \mathrm{Ie}$

Sp. lipoferum RG5b

$S p$. lipoferum USA5C

\begin{tabular}{|c|c|c|}
\hline \multirow[b]{2}{*}{ Phenotype } & \multicolumn{2}{|c|}{ Antibody stain* } \\
\hline & $\mathrm{K}_{\mathrm{I}}$ & $\mathrm{K}_{2}$ \\
\hline $\mathrm{Nif}^{+}$ & +4 & +4 \\
\hline Nif- & - & - \\
\hline Nif- & - & - \\
\hline $\mathrm{Nif}^{+}$ & +4 & +4 \\
\hline Nif- & - & - \\
\hline $\mathrm{Nif}^{-}$ & - & - \\
\hline $\mathrm{Nif}^{-}$ & - & - \\
\hline $\mathrm{Nif}^{+}$ & \pm & \pm \\
\hline $\mathrm{Nif}^{+}$ & \pm & \pm \\
\hline $\mathrm{Nif}^{+}$ & \pm & \pm \\
\hline $\mathrm{Nif}^{+}$ & +3 & +3 \\
\hline $\mathrm{Nif}^{+}$ & \pm & \pm \\
\hline $\mathrm{Nif}^{+}$ & \pm & \pm \\
\hline $\mathrm{Nif}^{+}$ & \pm & \pm \\
\hline $\mathrm{Nif}^{+}$ & \pm & \pm \\
\hline $\mathrm{Nif}^{+}$ & \pm & \pm \\
\hline $\mathrm{Nif}^{+}$ & +2 & $\overline{+} 2$ \\
\hline $\mathrm{Nif}^{+}$ & +2 & +2 \\
\hline $\mathrm{Nif}^{+}$ & \pm & \pm \\
\hline
\end{tabular}

* -, Negative; \pm , trace; + I feeble to +4 maximal. 
homologous nitrogenase proteins from $K$. pneumoniae M5aI at maximal fluorescence. No cross-reaction was observed with nitrogenase from Rhizobium japonicum, Clostridium pasteurianum or Azotobacter chroococcum except for traces of staining of the Fe protein of $A z$. chroococcum. An interesting observation was the good cross-reaction with analogous nitrogenase from Bacillus polymyxa, which suggested close structural homology at least of the antigenic sites of the B. polymyxa and $K$. pneumoniae protein. Glutamine synthetase was studied because it is involved in the regulation of nitrogenase synthesis (Streicher et al., 1974; Tubb, 1974); nitrate reductase, xanthine oxidase and formate dehydrogenase were tested because, like nitrogenase, they are molybdoenzymes; serum albumin was a blank control; none was stained by $\mathrm{K}_{\mathrm{I}}$ or $\mathrm{K} 2$.

\section{Reactions with natural dinitrogen-fixing bacteria}

Table 3 records tests of $\mathrm{K}_{\mathrm{I}}$ and $\mathrm{K}_{2}$ with toluene-treated bacteria, grown as described in Methods. The parent strain stained well; ammonium repressed the synthesis of stainable material. A Nif ${ }^{+}$Klebsiella sp. of serotype 54 stained well; a comparable Nif ${ }^{-}$species did not. Nif- $K$. aerogenes strains did not stain at all but, as expected from the behaviour of its nitrogenase proteins, $B$. polymyxa stained well. Trace cross-reactions were seen with some aerobic and anaerobic dinitrogen-fixing bacteria but the only substantial cross-reactions were seen with two strains of Spirillum lipoferum designated 'small' by Dr J. Dobereiner (personal communication). These, like $B$. polymyxa, probably have a nitrogenase which has some structural homology to Klebsiella nitrogenase.

\section{Tests with mutants and strains carrying nif plasmids}

Table 4 records tests with well-characterized mutants of $K$. pneumoniae M5aI and organisms carrying the nif plasmids RP4I (Dixon, Cannon \& Kondorosi, I976; Cannon, Dixon \& Postgate, 1976; Cannon \& Postgate, I976), FN68 (Cannon et al., 1976) and uncharacterized plasmids (Dixon \& Postgate, 1972). Klebsiella pneumoniae 107 is a mutant of strain M5a deleted throughout the nif region and showed no cross-reaction at all. Mutant UN3 8 , a point Nif- mutant (St John et al., 1975), had lost both immunological and biochemical Mo-Fe protein activity; mutant 279 showed the reverse pattern - absence of activity and antigen for the $\mathrm{Fe}$ protein. Mutant 285 lacked the $\mathrm{Fe}$ protein activity but retained an antigenic polypeptide. Escherichia coli JC5466 with the plasmids RP4I or FN68 added (Cannon et al., 1976) reduced acetylene and had both component proteins. Similarly, E. coli C603 with non-characterized plasmids added (Dixon \& Postgate, 1972) reduced acetylene and had both component proteins irrespective of whether the nif genes remained on the plasmid, as was the case for C-M9 and C-L4 (Cannon et al., 1974b), or were integrated into the chromosome, as for C-M7 (Cannon et al., 1974a). The strains of Az. vinelandii (Shah et al., 1973; Brill, 1976) were the mutants used by Cannon \& Postgate (1976) to correct structural nif mutations with $K$. pneumoniae nif genes on RP4I. Mutants FCIO, FC9I and FCIOO showed cross-reaction towards the nitrogenase protein in which they were originally defective (as UWIO, UW9I and UWI00) but, surprisingly, no cross-reaction with FA to the Klebsiella nitrogenase protein they did not need. Selective regulation of chromosomal and plasmid nif would seem to be the only interpretation. Strains of VKSI and the parent LT7-I20I of S. typhimurium showed the expected pattern of cross-reaction but 602 was unsatisfactory: both VKSI and 602 were strongly $\mathrm{Nif}^{+}$(Cannon et al., 1976; Postgate \& Krishnapillae, unpublished). Agrobacterium tumefaciens, though phenotypically Nif-, carried RP4I (Dixon et al., 1976) and formed antigens to serum prepared against 
Table 4. Application of immunofluorescence to genetic analysis of nitrogen-fixing derivatives of Klebsiella, Azotobacter, Salmonella, Agrobacterium and Escherichia

\begin{tabular}{|c|c|c|c|c|c|c|c|c|}
\hline \multirow[b]{3}{*}{ Micro-organism } & \multirow{2}{*}{\multicolumn{2}{|c|}{ Known 'Nif' phenotype }} & \multirow{3}{*}{$\begin{array}{c}\text { Plasmid } \\
\text { introduced }\end{array}$} & \multicolumn{3}{|c|}{ Altered 'Nif' phenotype } & \multirow{2}{*}{\multicolumn{2}{|c|}{ Antibody stain $\dagger$}} \\
\hline & & & & & Presumed & & & \\
\hline & Biochemical & CRM* & & Code & CRM & reduction & $\mathbf{K}_{\mathbf{I}}$ & $\mathbf{K}_{2}$ \\
\hline \multicolumn{9}{|l|}{$K$. pneumoniae } \\
\hline M5aI & $I^{\mathrm{k}} I I^{\mathrm{k}}$ & $I^{\mathbf{k}} \mathbf{I I}^{\mathbf{k}}$ & . & . & . & + & +4 & +4 \\
\hline 107 & $\mathrm{I}^{-} \mathrm{II}^{-}$ & $\mathrm{I}^{-} \mathrm{II}^{-}$ & . & . & . & - & - & - \\
\hline UN318 & $\mathbf{I}^{-} \mathbf{I I}^{\mathbf{k}}$ & $I^{-}-I^{k}$ & . & . & . & - & - & +4 \\
\hline 279 & . & . & . & . & $\mathbf{I}^{\mathbf{k}} \mathbf{I}^{-}$ & - & +2 & - \\
\hline 285 & . & . & . & . & IkII- $^{-}$ & - & +4 & +2 \\
\hline \multicolumn{9}{|l|}{ E. coli } \\
\hline JC5466 & . & . & $\cdot$ & & $\mathbf{I}^{-} \mathbf{I}^{-}$ & - & - & - \\
\hline JC5466 & . & . & FN68 & JC5466(FN68) & $I^{k} I^{k}$ & + & +4 & +4 \\
\hline JC5466 & . & . & $\mathbf{R P}_{4} \mathbf{I}$ & JC5466(RP4I) & $\mathbf{I}^{\mathbf{k}} \mathbf{I}^{\mathbf{k}}$ & + & +4 & +4 \\
\hline $\mathrm{c} 603$ & . & . & $\cdot$ & . & $\mathbf{I}^{-} \mathbf{I I}^{-}$ & - & - & - \\
\hline $\mathrm{c} 603$ & . & . & NC $\ddagger$ & C-M7 & $\mathbf{I}^{\mathbf{k}} \mathbf{I I}^{\mathbf{k}}$ & + & +4 & +4 \\
\hline $\mathrm{c} 603$ & . & . & $\mathrm{NC}$ & C-M9 & $\mathbf{I}^{\mathbf{k}} \mathbf{I}^{\mathbf{k}}$ & + & +4 & +4 \\
\hline $\mathrm{c} 603$ & . & - & NC & C-L4 & $\mathbf{I}^{\mathbf{k}} \mathbf{I I}^{\mathrm{k}}$ & + & +4 & +4 \\
\hline \multicolumn{9}{|l|}{ S. typhimurium } \\
\hline LT7-I 201 & . & . & . & . & $\mathrm{I}^{-} \mathrm{II}^{-}$ & - & - & - \\
\hline LT7-I 201 & . & . & RP4I & VKSI & $\mathbf{I}^{\mathbf{k}} I^{\mathbf{k}}$ & + & +2 & +4 \\
\hline LT7-1 201 & . & . & FN68 & 602 & $\mathbf{I}^{\mathbf{k}} \mathbf{I I}^{\mathbf{k}}$ & + & \pm & +2 \\
\hline \multicolumn{9}{|l|}{ A. tumefaciens } \\
\hline 544 & . & . & . & . & $\mathrm{I}^{-} \mathrm{II}^{-}$ & - & - & - \\
\hline 544 & . & & RP4I & 544 & $\mathbf{I}^{\mathbf{k}} \mathbf{I I}^{\mathbf{k}}$ & + & +2 & +2 \\
\hline \multicolumn{9}{|l|}{$A z$. vinelandii } \\
\hline OP & $I^{a} I I^{a}$ & $\mathbf{I}^{\mathrm{a}} \Pi^{\mathrm{a}}$ & . & . & . & + & \pm & \pm \\
\hline UWIO & $\mathbf{I}^{-} \mathbf{I I}^{\mathrm{a}}$ & $\mathbf{I}^{\mathrm{a}} \mathbf{I}^{\mathrm{a}}$ & $\mathbf{R P}_{4} \mathbf{I}$ & FCro & $\mathbf{I}^{\mathbf{a k} \mathbf{I}} \mathbf{I}^{\mathbf{a k}} \S$ & + & +4 & \pm \\
\hline UW9I & IaII- $^{-}$ & $\mathbf{I}^{\mathbf{a}} \mathbf{I I}^{\mathbf{a}}$ & $\mathrm{RP}_{4} \mathbf{I}$ & FC9I & $\mathbf{I}^{\mathrm{ak}} \mathbf{I I}^{\mathrm{ak}}$ & + & \pm & $\overline{+}_{4}$ \\
\hline UWIOO & $\mathrm{I}^{-} \mathrm{II}^{\mathrm{a}}$ & $I^{a} I I^{a}$ & RP4I & FC100 & $I^{a k} I I^{a k}$ & + & +4 & \pm \\
\hline
\end{tabular}

* Cross-reacting material determined immunologically: k designates Klebsiella; a, Azotobacter origin.

$\dagger-$, Negative; \pm , trace; + I feeble to +4 maximal.

NC, Not sufficiently characterized to be named.

$\$$ Dominance of chromosomal over plasmid DNA unknown. 
$K$. pneumoniae proteins. The lower degree of staining may indicate that this nitrogenase was present in lower concentration or was conformationally distorted.

The use of specific, homologous fluorescent antibodies against the Mo-Fe and $\mathrm{Fe}$ proteins of Klebsiella nitrogenase permitted the rapid and precise detection of these components in mutants and derivatives carrying Klebsiella nif genes. Such tests could be a useful tool for characterization of mutants and derivatives which synthesize inactive nitrogenase polypeptides. Differing degrees of cross-reactions, as noted with B. polymyxa and two Sp. lipoferum strains, may be used to study the relatedness of nitrogenase from various origins.

This work was supported through a post-doctoral fellowship given by the National Research Council (Canada) to R.J.R. tenable at the A.R.C. Unit of Nitrogen Fixation, University of Sussex. The author wishes to thank Drs F. Bergersen, R. C. Bray, F. C. Cannon, R. A. Dixon, R. R. Eady, C. Kennedy, L. E. Mortenson, B. E. Smith, S. L. Streicher and M. G. Yates for supplying pure nitrogenase proteins and micro-organisms; Dr P. Benjamen for the microscope facilities; and Professor J. R. Postgate for the constructive criticism of the manuscript.

\section{REFERENCES}

Biggins, D. R. \& Postgate, J. R. (I969). Nitrogen fixation by cultures and cell-free extracts of $M y c o-$ bacterium flavum 301. Journal of General Microbiology 56, 181-193.

BoHLOOL, B. B. \& ScHMIDT, E. L. (I968). Nonspecific staining: its control in immunofluorescence examination of soil. Science 162, 1012-1014.

BRILL, W. J. (1976). Control of nitrogenase synthesis in Azotobacter vinelandii. In Symbiotic Nitrogen Fixation in Plants, International Biological Programme, vol. 7, pp. 39-46. Edited by P. S. Nutman. London: Cambridge University Press.

Brill, W. J., Westphal, J., Stizghorst, M., Davis, L. C. \& Shah, V. K. (1974). Detection of nitrogenase components and other non-heme iron proteins in polyacrylamide gels. Analytical Biochemistry 60 , 237-241.

Cannon, F. C. \& Postgate, J. R. (1976). Expression of Klebsiella nitrogen fixation genes (nif) in Azotobacter. Nature, London 260, $271-272$.

Cannon, F. C., Dixon, R. A. \& Postgate, J. R. (I974a). Chromosomal integration of Klebsiella nitrogen fixation genes in Escherichia coli. Journal of General Microbiology 80, 227-239.

Cannon, F. C., Dixon, R. A., Postgate, J. R. \& Primrose, S. B. (1974b). Plasmids formed in nitrogenfixing Escherichia coli-Klebsiella pneumoniae hybrids. Journal of General Microbiology 80, 24I-25I.

Cannon, F. C., Dixon, R. A. \& Postgate, J. R. (1976). Derivation and properties of F-prime factors in Escherichia coli carrying nitrogen fixation genes from Klebsiella pneumoniae. Journal of General Microbiology 93, I I I-I 25.

Davis, L. C., Shah, V. K., Brill, W. J. \& ORME-Johnson, W. H. (1972). Nitrogenase. II. Changes in the EPR signal of component I (iron-molybdenum protein) of Azotobacter vinelandii nitrogenase during repression and derepression. Biochimica et biophysica acta 256, 512-523.

Dixon, R. A. \& Postgate, J. R. (1972). Genetic transfer of nitrogen fixation from Klebsiella pneumoniae to Escherichia coli. Nature, London 237, 102-103.

Dixon, R. A., Cannon, F. C. \& Kondorosi, A. (1976). Construction of a P plasmid carrying nitrogen fixation genes from Klebsiella pneumoniae. Nature, London 260, 268-27I.

EAdy, R. R. \& Postgate, J. R. (1974). Nitrogenase. Nature, London 249, 805-810.

EAdy, R. R., Smith, B. E., Cook, K. A. \& Postgate, J. R. (1972). Nitrogenase of Klebsiella pneumoniae. Biochemical Journal 128, 655-675.

Goldman, M. (1968). Fluorescent Antibody Methods. New York: Academic Press.

Gornall, A. G., Bardawinl, C. J. \& DAVID, M. M. (1949). Determination of serum proteins by means of the biuret reaction. Journal of Biological Chemistry 177, 751-756.

Hino, S. \& Wilson, P. W. (1957). Nitrogen fixation by a facultative bacillus. Journal of Bacteriology 75 , 403-408.

KWAPINSKY, J. B. G. (1972). Methodology of Immunochemical and Immunological Research. London: WileyInterscience.

NAIRN, R. C. (1969). Fluorescent Protein Tracing. London: Livingstone.

Newton, J. W., WILson, P. W. \& BuRRIs, R. H. (1953). Direct demonstration of ammonia as an intermediate in nitrogen fixation by Azotobacter. Journal of Biological Chemistry 204, 445-45I. 
SCHMIDT, E. L. (1973). Fluorescent antibody techniques for the study of microbial ecology. Bulletin of the Ecological Research Committee (Stockholm) 17, 67-76.

Shah, V. K., Davis, L. C., Gordon, J. K., Orme-Johnson, W. H. \& BrILL, W. J. (1973). Nitrogenase. III. Nitrogenaseless mutants of Azotobacter vinelandii: activities, cross-reactions and EPR spectra. Biochimica et biophysica acta 292, 246-255.

Smith, B. E., Thorneley, R. N. F., YATES, M. G., EAdy, R. R. \& Postgate, J. R. (1976). Structure and function of nitrogenase from Klebsiella pneumoniae and Azotobacter chroococcum. Proceedings of the First International Symposium on Nitrogen Fixation, vol. I, pp. 150-176. Edited by W. E. Newton and C. J. Nyman. Pullman: Washington State University Press.

St John, R., Johnston, H. M., Semdan, C., Garfinkel, D., Gordon, J. K., Shah, V. K. \& Brill, W. J. (1975). Biochemistry and genetics of Klebsiella pneumoniae mutant strains unable to fix $\mathrm{N}_{2}$. Journal of Bacteriology 121, 759-765.

Streicher, S. L., Shanmugan, K. T., Ausubel, F., Morandi, C. \& Goldberg, R. B. (1974). Regulation of nitrogen fixation in Klebsiella pneumoniae: evidence for a role of glutamine synthetase as a regulator of nitrogenase synthesis. Journal of Bacteriology $120,815-821$.

TuBB, R. S. (1974). Glutamine synthetase and ammonium regulation of nitrogenase synthesis in Klebsiella. Nature, London 251, 481-485. 